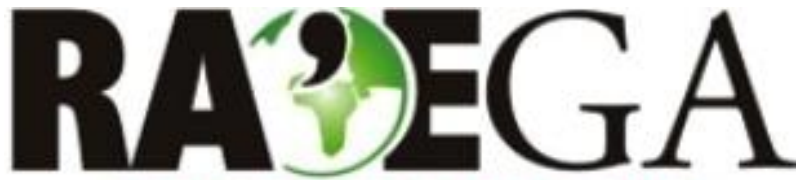

O ESPAÇO GEOGRÁFICO EM ANÁLISE

\title{
PAISAGEM CULTURAL E ESPAÇOS DE REPRESENTAÇÃO DA COLÔNIA ÁGUA BRANCA, MUNICÍPIO DE SÃO MATEUS DO SUL/PR
}

\section{CULTURAL LANDSCAPE AND SPACES OF REPRESENTATION AT AGRICULTURAL COMMUNITY OF ÁGUA BRANCA, SÃO MATEUS DO SUL/PR}

\author{
Liliane Monfardini Fernandes Lucena $^{1}$
}

\section{RESUMO}

Os estudos sobre a temática da Paisagem Cultural têm sido retomados desde o final da década de 1970, a partir de uma releitura de sua concepção possibilitada pelo desenvolvimento da Geografia Humanista, a Geografia das Representações e do pensamento fenomenológico. Este amadurecimento conceitual foi imprescindível para sua revalorização no campo acadêmico e aplicação nas políticas públicas. Destaca-se nesta pesquisa a associação deste tema ao patrimônio cultural, pelos órgãos internacionais e nacionais, o que proporcionou ainda mais sua popularização, como a UNESCO (Organização das Nações Unidas para a Educação, a Ciência e a Cultura) e o IPHAN (Instituto do Patrimônio Histórico e Artístico Nacional), que criaram um instrumento de preservação denominado "Paisagem Cultural". Partindo da tese de que a paisagem cultural deve ter a dimensão do mundo vivido dos seus moradores, propõe-se o desenvolvimento de uma metodologia que evidencie a duplicidade de sentido que a paisagem porta. A proposta está embasada em Henri Lefebvre, na tríade - práticas espaciais/espaços de representação/ representações do espaço e o objeto de estudo para aplicação desta metodologia foi a colônia agrícola Água Branca, situada no município de São Mateus do Sul/ PR. Desta forma, acredita-se que a Paisagem Cultural como espaço vivido converge para a compreensão tanto na perspectiva teórica da Geografia das Representações como na perspectiva aplicada, aos órgãos de preservação histórica e cultural.

PALAVRAS-CHAVE: Espaço vivido; Patrimônio Histórico e Cultural; imigração europeia; Geografia.

\section{ABSTRACT}

The studies on the theme of Cultural Landscape have been resumed since the end of 1970s, from a reinterpretation of its conception made possible by the evolution of Humanistic Geography, the Geography of Representations and the phenomenological thought. This conceptual ripening was essential for its revaluation in the academic field and application in public politics. Stand out in this research the association of this theme to the cultural heritage, by international and national institutes, providing even more its popularization, among them UNESCO (United Nations Educational, Scientific and Cultural Organization) and IPHAN (National Institute of Historical and Artistic Heritage), that created an instrument of preservation named "Cultural Landscape". Starting from the thesis that the cultural landscape must have the dimension of the lived world of its residents, it proposes the use of a methodology that evidences the duplicity of the meaning that the landscape regard. The propos is based in Henri Lefebvre, in the triad - spatial practices/spaces of representation/ representations of space and the object of study for the application of this methodology was the agricultural community Água Branca, located in São Mateus do Sul/PR. In this way, it is believed that the Cultural Landscape as living space converges to the understanding both the theoretical perspective of Geography of the Representations as in the applied perspective, to the institutes of historical and cultural preservation.

KEY-WORDS: Living space; Historical and Cultural Heritage; European immigration; Geography

Recebido em: 11/02/2016

Aceito em: 06/10/2016

\footnotetext{
${ }^{1}$ Universidade Federal do Paraná, Curitiba/PR e-mail: llucena71@yahoo.com.br
} 


\section{LUCENA,L.M.F. \\ PAISAGEM CULTURAL E ESPAÇOS DE REPRESENTAÇÃO. ANÁLISE DA COLÔNIA DE ÁGUA BRANCA, MUNICIPIO DE SÃO MATEUS DO SUL/PR}

\section{INTRODUÇÃo}

Nas últimas décadas, discussões e estudos de caso sobre o tema "paisagem cultural" vêm sendo bastante intensificados pela nova abordagem cultural da Geografia. Destacase, principalmente, a associação desta temática ao patrimônio pelos órgãos internacionais e nacionais, o que tem proporcionado ainda mais sua popularização. Vale lembrar a recente titulação que o Rio de Janeiro recebeu, em 2012, pela Organização das Nações Unidas para a Educação, a Ciência e a Cultura (UNESCO), sendo incluída na Lista de Patrimônios da Humanidade, pela categoria que porta o mesmo nome: "paisagem cultural".

No bojo desta discussão, tem-se a forma como este tema vem sendo aplicado pelo principal órgão de preservação cultural nacional, o Instituto do Patrimônio Histórico e Artístico Nacional (IPHAN), que também criou legislação própria em 2009. Passados mais de seis anos da criação desta portaria, até o presente momento, nenhuma paisagem cultural foi chancelada em nível nacional. Um dos problemas levantados pelo próprio Instituto está na dificuldade de consolidação de um "Plano de Gestão compartilhado" entre os diversos órgãos e entidades públicas e privadas que atuam sobre a paisagem delimitada. Mas há outras questões que serão abordadas, que implicam na delimitação da área a ser chancelada e consequentemente, na conclusão dos Planos de Gestão e consequente pactuação. Busca-se, então, pelo olhar da Geografia, resgatar alguns princípios de estudo sobre paisagem que direcionariam para construção de uma metodologia própria que evidencie a "visão integradora entre o homem e o meio ambiente natural" (IPHAN, 2009a, p. 17).

Realiza-se, então, a análise da paisagem de uma antiga colônia agrícola denominada até hoje de Água Branca, no município de São Mateus do Sul/PR. Com esta nova metodologia, procura-se trazer uma contribuição para o IPHAN sobre os estudos da paisagem cultural. A paisagem cultural de Água Branca, devido seu aspecto de "perpetuação histórica" de uso e preservação dos seus principais espaços de representação e da territorialidade construída pelo grupo de moradores, potencializam-na em sua identificação como patrimônio histórico, seja municipal, estadual e/ou federal. Esta colônia pertence a um grupo de dezenas de colônias agrícolas implantadas durante um período histórico brasileiro (final do século XIX e início do século $X X)$, basicamente nos estados do Paraná, Santa Catarina e Rio Grande do Sul, que marcaram o início de uma nova fase da ocupação territorial em nível nacional, seja pela necessidade de interiorização da população, seja pela nova proposta fundiária de utilização de minifúndios, em contraposição aos latifúndios que predominavam até então.

\section{MATERIAIS E MÉTODOS}

Optou-se aqui por uma abordagem de análise teórica e metodológica que identifica na paisagem cultural um valor social atribuído, (re)significado pela experiência de vida do grupo social que participou historicamente e espacialmente da construção deste espaço e desta paisagem, tendo-a como valores simbólicos, afetivos, os referenciais espaciais e históricos (LUCHIARI, 2001); por isso, essa paisagem torna-se uma representação do mundo construído pelo grupo que ali vive (LEFEBVRE, 1974).

A representação é "um fenômeno da consciência" que acompanha temporariamente uma sociedade e conceitua um dado objeto ou conjunto de objetos (LEFEBVRE, 1974). O filósofo Henri Lefebvre é o principal referencial teórico norteador para construção desta metodologia de abordagem, que desenvolveu sua teoria sobre o espaço social, compreendendo-o como sendo aquele que integra e aglutina os termos mental, social e físico. O espaço, por si, não existe, é uma criação humana situada no nível do intelecto, do mental. Somente quando está associado ao sujeito ou grupo social ganha existência, sentido. É assim que acontece com os lugares, paisagens, arquiteturas, que só possuem significado por estarem relacionados à existência de indivíduos que os utilizam. 


\section{LUCENA,L.M.F. \\ PAISAGEM CULTURAL E ESPAÇOS DE REPRESENTAÇÃO. ANÁLISE DA COLÔNIA DE ÁGUA BRANCA, MUNICIPIO DE SÃO MATEUS DO SUL/PR}

Dessa forma, parte-se do entendimento de que tanto o espaço como a paisagem são categorias geográficas de análise criadas pelo homem para compreensão das coisas e suas relações no mundo, cujas formas, sentidos e significados advêm dos valores e práticas de uma sociedade. Ou seja, estas categorias posicionamse como instrumentos mediadores para "representar" a realidade que o homem consegue apreender com seu conhecimento, o qual está sempre em construção, fazendo novas descobertas.

Gil Filho (2005) também, ao discorrer sobre a Geografia das Representações, inicia seu discurso afirmando que "a representação é uma forma de conhecimento. Mesmo que o tempo e o espaço gerem determinadas formas de representação, é na dualidade sujeito-objeto que reside o denominador comum que pode conceber toda forma de representação" (2005, p. 51). Existe, portanto, também para ele, um terceiro elemento - a representação, criada a partir da relação sujeito-objeto.

O mesmo autor também interpreta o espaço e a paisagem como elementos ou conceitos representacionais, integrantes deste "denominador comum". Para justificar esta afirmativa, relaciona a compreensão do conceito de espaço com a compreensão do mundo e do ser. O "existir" pressupõe estar/ocupar um espaço, o qual não é homogêneo e constitui a base para as práticas sociais. Dessa maneira, o mundo ou a realidade está subdivida em duas esferas: a fenomênica presencial e a das representações: a esfera presencial "é a esfera da coisa em si, do mundo dos significantes, a semelhança do conceito de lefebvriano de prática espacial" (GIL FILHO, 2005, p. 53-54). E a esfera das representações "é esfera das coisas para si, da instância das propriedades do objeto, o reino simbólico" (2005, p. 54). Desta feita, o espaço e a paisagem entram neste denominador comum, a mediação entre sujeito-objeto ou adotando a conceituação de Lefebvre (2006 [1980]) representante (sujeito) - representação (espaço e paisagem) - representado (objeto).
Esta primeira tríade - representanterepresentação- representado deriva da compreensão da primeira trialética de Lefebvre a "trialética do ser", discutidas e incorporadas por Soja (1996) e Marques e Barreto (2012). Os elementos espaço e tempo são condicionantes e também resultados da produção da sociedade, seu terceiro elemento que compõe a trialética espaço, tempo e sociedade. Cada sociedade produz um espaço com suas especificidades. Lefebvre, assim, afirma: "O espaço contém certas representações dessa tripla interferência de relações sociais. Pelas representações simbólicas, o espaço mantém relações sociais em estado de coexistência e coesão" (LEFEBVRE, 1974, p. 42, tradução nossa). A tripla interferência de relações sociais são a reprodução biológica, a reprodução da força de trabalho e a reprodução das relações sociais de produção. Emerge deste primeira trialética, portanto, a segunda trialética "Trialética do Espaço", que, na verdade, como elucidam Marques e Barreto (2012, p. 91), "estão duplamente determinados e da mesma forma duplamente designados". A primeira, de abordagem linguística ou semiótica é composta pela "prática espacial" - "representações do espaço" e "espaços de representação", e a segunda tríade, de abordagem fenomenológica, refere-se aos espaços: "percebido" - "concebido" - "vivido".

Para Lefebvre (1974), essa tríade espacial jamais pode ser tomada como um modelo abstrato, distanciado da concretude da vida, sob pena de perder sua força teórica:

[...] A triplicidade: percebido-concebido-vivido (espacialmente: prática do espaçorepresentação do espaço - espaços de representação) perde seu escopo se the é atribuído o estatuto de um 'modelo' abstrato. Ou ela agarra o concreto (e não o 'imediato'), ou ela tem importância apenas reduzida, a de uma mediação ideológica entre muitas outras. (LEFEBVRE, 1974, p. 50, tradução nossa). [...] Pode-se supor que a prática espacial, as representações do espaço e os espaços de representação intervêm diferentemente na produção do espaço: segundo suas qualidades e propriedades, segundo as sociedades (modos 


\section{LUCENA,L.M.F. \\ PAISAGEM CULTURAL E ESPAÇOS DE REPRESENTAÇÃO. ANÁLISE DA COLÔNIA DE ÁGUA BRANCA, MUNICIPIO DE SÃO MATEUS DO SUL/PR}

de produção), segundo as épocas. As relações entre esses três momentos - o percebido, o concebido e o vivido - nunca são simples, nem estáveis, nem mais 'positivas', no sentido em que esse termo se oporia ao 'negativo', ao indecifrável, ao não dito, ao interdito, ao inconsciente. Esses momentos e suas conexões cambiantes são 'conscientes'? Sim, e, geralmente, ignorados. Pode-se declará-los inconscientes? Não, pois geralmente são ignorados e a análise os retira da sombra, com riscos e equívocos. Tais conexões, das quais sempre é preciso falar, o que não equivale a saber, mesmo 'inconscientemente' (LEFEBVRE, 1974, p. 57, tradução nossa). ${ }^{2}$

Estes três pares de elementos - prática espacial e percebido, espaço de representação e vivido, representações do espaço e concebido, assim associados pelo próprio autor, não se relacionam como sinônimos. Estes três elementos binários constituem o espaço social. Os espaços - vivido, percebido e concebido propõe referir-se à experiência do indivíduo ou grupo em relação à realidade apresentada. Os espaços de representação, as práticas espaciais e as representações do espaço correspondem à materialidade, aos lugares, arquiteturas, territórios; são as representações criadas pelos sujeitos ou grupos sociais.

\footnotetext{
2 Texto original: "La triplicité: perçu-conçu-vécu (spatialement: pratique de l'espace - représentation de l'espace - espaces de représentation) perd as portée si on lui attribue statut d'un 'modele' abstrait. Ou bien ele saisit du concret (et non de l' 'immédiat'), ou bien ele n'a qu'une importance restreinte, celle d'une médiation idéologique parmi beaucoup d'autres. [...] On peut supposer que la pratique spatiale, les représentations de l'espace et les espaes de représentation interviennent différemment dans la production de l'espace: selon leurs qualités et propriétés, selon les sociétés (mode de production), selon les époques. Les rapports entre ces trois moments - le perçu, le conçu, le vécu - ne sont jamais ni simples ni stables ils se sont pas davantage 'positifs' au sens où ce terme s'opposerait au 'negatif' à l'indéchiffrable, au non-dit, à l'interdit, à l'inconscient. Ces moments et leurs connexions changeantes sont-ils conscients? Oui, et cependant méconnus. Peut-on les déclarer 'inconscients'? Oui, puisqu'en general ignores, et que l'analyse les tire de l'ombre, non sans risque d'erreurs. Ces connexions, il a toujours fallu les parles, ce qui n'équivaut pas à les savoir, meme 'inconsciemment'."
}

Para Soja (1996, p. 61), a obra de Lefebvre organiza-se em torno de uma thirding (terceira dimensão), pelo interesse em "romper" a dialética do vivido e do concebido, o mundo material e o pensamento de cada indivíduo sobre o mesmo. A leitura de Soja sobre Lefebvre o faz criar o conceito de "thirding", uma "trialética do espaço" que é ao mesmo tempo uma combinação de termos para a compreensão do espaço social: a prática social, a representação do espaço e o espaço de representação, espaços estes resultantes da forma como o homem se relaciona com o mundo.

o espaço vivido ou espaço de representação, emerge como síntese entre as combinações, os conflitos sociais daquele grupo social que ali vive sobre os espaços - percebido e concebido. É nos espaços de representação onde as formas simbólicas ganham espacialidade, e, por isso, concebem uma nova dimensão, como foi exposto por Gil Filho (2005, p. 54), para a construção de uma Geografia das Representações ou do Conhecimento simbólico.

Em trabalho anterior de Gil Filho (2003), o espaço de representação é proposto como uma categoria-chave para a análise cultural em Geografia:

O espaço de representação é o reino da esfera consensual, e a expressão da esfera reificada da consciência coletiva, o momento em que o atributo de ser uma coisa se torna típica realidade objetiva. Sua prática cotidiana é a própria representação e sua expressão é o condicionamento do poder exercido. $O$ espaço de representação é um espaço vivo com ligações culturais, lócus da ação e das situações vivenciadas(GIL FILHO, 2003, p. 1).

Na dimensão do vivido, a vida cotidiana do morador e do usuário é que constrói os espaços - concebido e percebido - formas, usos, funções e ritmos previstos e imprevistos, de acordo com suas necessidades e ansiedades. A vida cotidiana, segundo Lefebvre (1991a [1968]), é composta basicamente por três eixos estruturadores da sociedade capitalista, que são o trabalho, a família e o lazer. O “homem 


\section{LUCENA,L.M.F. \\ PAISAGEM CULTURAL E ESPAÇOS DE REPRESENTAÇÃO. ANÁLISE DA COLÔNIA DE ÁGUA BRANCA, MUNICIPIO DE SÃO MATEUS DO SUL/PR}

cotidiano" vive a relação entre a opressão do mundo do trabalho, o mundo doméstico das relações familiares e a liberdade da festa - o momento de lazer, descanso, como forma de oposição e de compensação ao trabalho. Assim, é por meio das representações que a vida cotidiana estabelece a relação dialética entre o ser e o conhecer, o representante e o representado, o vivido e o concebido. As representações, sob a forma de signos e símbolos, tomam o lugar das coisas como um substituto da presença na ausência, tornando possível designar por meio da linguagem, o objeto ausente, preenchendo sua ausência com as representações constituídas por eles (LEFEBVRE, 2006 [1980]).

Desse modo, no espaço vivido ou de representação, as relações cotidianas de trabalho, moradia, lazer, e poder-se-ia acrescentar a circulação (que faz o papel de interligação destes espaços e práticas), estão evidentes pela presença e distribuição físicoespacial destes elementos representativos do trabalho e moradia, ou seja, nos elementos construtivos, espaços de produção, moradia, encontro para lazer e nas diversas funções e usos que o mesmo espaço pode possibilitar. A vida cotidiana e suas relações rotineiras, seja num bairro, numa cidade, foram estabelecidas ao longo de um processo histórico-espacial construído, pautado ora pelo espaço percebido, cujas práticas são desenvolvidas ou induzidas por meio das condições físicas encontradas, as quais geraram possibilidades e formas de uso, ora pelo espaço concebido, cujas práticas são norteadas por uma idealização, planejamento macro de uma ordem distante (estado, capitalistas, etc.) que impõe determinadas regulações, formas e estruturas espaciais, etc. Mas, também, como Lefebvre lembra, a prática da vida cotidiana, pautada nas necessidades e valores sociais do grupo, adapta-se e reinterpreta estes espaços e ritmos na forma como lhes convém, constituindo seus espaços de representação, seu espaço vivido. Soja (1996), em sua interpretação de Lefebvre, explicita que o espaço vivido é entendido na simultaneidade que passa do real ao imaginado e a ele retorna, sendo este o lugar da experiência e da ação estruturada individual e coletivamente.

Será, portanto, a partir desta referência sobre o espaço vivido que se desenvolve a análise sobre a colônia de Água Branca. A partir da identificação e análise do espaço vivido e dos espaços de representação criados, propõe-se avaliar sob quais argumentos este espaço ou território poderia ou não ser considerado uma paisagem cultural, seja pela existência das características apontadas pela Geografia, seja pelas características valorizadas pelos órgãos de preservação nacional.

Os espaços de representação sintetizam o lugar criado e recriado pelos moradores, onde seus valores simbólicos foram construídos/espacializados e são vivenciados de geração a geração. Alguns destes espaços de representação estão ativos, como que perpetuados pelas diversas gerações, outros espaços foram (re)significados e outros esquecidos.

Optou-se realizar o trabalho em três etapas, de acordo com o a análise de Lefebvre, identificando as três dimensões que caracterizam o espaço social e o espaço vivido, sendo que a primeira consiste em um levantamento documental e cartográfico sobre as origens da instalação das colônias agrícolas no vale médio do Iguaçu e sobre a colônia Água Branca, mais especificamente. Esta primeira etapa foi necessária para compreender o processo de ocupação e transformação social, econômica e espacial da área em questão e para a realização de comparações com diversas situações encontradas atualmente. A análise da cartografia originária Água Branca obtida pelo ITCG (Instituto de Terras Cartografia e Geociência do Paraná) com as imagens satélites atuais possibilitaram identificar a preservação quase total de uma morfologia inicialmente proposta. Ou seja, a relação entre o espaço percebido e o espaço concebido lefebvriano.

A partir do levantamento histórico sobre a ocupação do local, foi possível realizar comparações com a segunda etapa do trabalho que objetivavam caracterizar o espaço vivido dos 


\section{LUCENA,L.M.F. \\ PAISAGEM CULTURAL E ESPAÇOS DE REPRESENTAÇÃO. ANÁLISE DA COLÔNIA DE ÁGUA BRANCA, MUNICIPIO DE SÃO MATEUS DO SUL/PR}

moradores e seus principais espaços de representação. Esta etapa consistiu na elaboração e aplicação, em duas fases, de questionários (primeira fase) e entrevistas (segunda fase), seguindo o entender de Moresi (2003) que caracteriza a entrevista como um importante instrumento de coleta de dados e informações, assim como para Britto Júnior e Feres Júnior (2011), que utilizam deste instrumento também como meio de comprovação ou esclarecimento de respostas, podendo ser associado a outros métodos de coleta de informações para melhorar a qualidade de um levantamento e de sua interpretação. A primeira fase, de cunho quantitativo, objetivou delinear o perfil étnico e profissional dos atuais moradores de Água Branca, bem como o atual uso das propriedades (abrangendo próximo dos $90 \%$ de todas as propriedades). A segunda fase de entrevistas, de cunho qualitativo, está relacionado ao uso dos espaços de Água Branca nas suas diversas atividades cotidianas e ao longo de um período histórico de aproximadamente 70 anos. A partir das entrevistas com grupos de três gerações diferentes, foi possível identificar os principais espaços de representação atuais destes moradores e como muitos destes espaços possuem vínculos históricos que se perpetuam socialmente desde sua criação, associados à criação da colônia inclusive.

Tanto as análises históricas e cartográficas como as entrevistas foram essenciais para realização da terceira etapa da metodologia, que foi a construção de uma cartografia que delineia a morfologia da paisagem cultural de Água Branca, pois a identificação dos espaços de representação permitiu também conhecer e delimitar a territorialidade dos moradores a partir do seu mundo vivido. Água Branca é uma dentre as diversas colônias agrícolas que foram instituídas quase simultaneamente, no vale médio do rio Iguaçu, estado do Paraná, no período entre o Brasil Império e o Brasil República. Foram ocupadas, basicamente, por imigrantes europeus, que transformaram a ocupação territorial da região sul do Brasil, trazendo uma nova organização espacial e sociocultural.

Esta colônia foi instalada em um contexto histórico-econômico brasileiro que atendia aos interesses do governo em fase de estruturação e aos interesses europeus, devido a diversas crises econômicas e socioculturais pelas quais aquele continente passava.

\section{RESULTADOS E DISCUSSÃO.}

O crescimento do fenômeno da emigração, entre os séculos XIX e XX, esteve associado, por Durkhein, Weber, Marx, dentre outros, ao desenvolvimento do sistema capitalista, isto é, com a industrialização e da urbanização ${ }^{3}$.

Os movimentos migratórios entram como "ferramenta estratégica" necessária para reequilíbrio e sobrevivência desta nova fase do sistema. É o que Lefebvre (1974) entenderia como a reorganização do espaço abstrato para emergir o espaço diferencial, num movimento de adaptação e conciliação entre a ordem distante e a ordem próxima, entre o Estado e os agentes capitalistas de um lado e a população, a classe trabalhadora, de outro.

A população europeia passou por dificuldades políticas e econômicas devastadoras. Em seu último século de vida na Polônia (século $\mathrm{XIX)}$, antes de migrarem para as Américas, a maioria das famílias polonesas ainda vivia sob o regime feudalista, enfrentando justamente a transição para o novo sistema econômico que já emergia na Europa Ocidental e dentro de seu país - o Capitalismo. Autores como Tchayanov (1976 [1924]), Kautsky (1968) e Abramovay (1992) analisaram situações semelhantes na Rússia (um dos países que invadiu a Polônia), em que coexistiam dois (ou mais) sistemas econômicos diferentes: entre aqueles que viviam na cidade,

\footnotetext{
${ }^{3}$ O período entre o final do século XVIII até o início do século XX foi a fase na qual a Europa vivenciou a Revolução Industrial e o crescimento de uma nova classe social no poder, concomitante à queda de muitas monarquias, o crescimento das cidades e a depauperação da população campesina. Esta foi a classe que mais sofreu por não encontrar mais espaço para subsistência.
} 


\section{LUCENA,L.M.F. \\ PAISAGEM CULTURAL E ESPAÇOS DE REPRESENTAÇÃO. ANÁLISE DA COLÔNIA DE ÁGUA BRANCA, MUNICIPIO DE SÃO MATEUS DO SUL/PR}

com o assalariamento do trabalho, a subdivisão das etapas da produção e a maximização da produção visando ao excedente (desenvolvimento capitalista), e aqueles que viviam no campo sob pressão do senhor feudal, que sobrevivia às custas da exploração campesina (sistema servil).

O Brasil encontrava-se numa fase econômica um tanto quanto diferente da situação enfrentada pela Europa. Se lá a densidade demográfica estava alta (mão de obra excedente no campo e na cidade), os salários eram baixos e faltavam terras para trabalhar, no Brasil, a situação era justamente o inverso, com falta de mão de obra, fartura de terras sem atividade e/ou devolutas e baixa densidade demográfica.

Mas, também, aqui, vivia-se um momento de transição e de contradições políticas, pois em menos de um século (durante o século XIX) o Brasil migrou do Regime Colonial para o Imperial e deste para o Republicano. Mesmo assim, as novas condições socioeconômicas mundiais e locais, sejam elas o fim do trabalho escravo, a necessidade de ocupar e povoar as fronteiras brasileiras, de substituir a mão de obra escrava pela assalariada e, ainda, de abastecer o mercado interno, proporcionaram a expansão de uma Política Oficial de Povoamento (PRADO JR., 1969). O governo brasileiro, ao final de sua fase colonial, ao longo de sua fase imperial e durante o início da época republicana (1818 a 1910), experimentou três grandes momentos de estímulo e implantação do povoamento de seu território, demarcando situações políticas e econômicas distintas. Cartas, decretos e leis foram emitidos para viabilização da intenção: ocupar o território brasileiro, principalmente suas fronteiras, e torná-lo viável e produtivo economicamente (IOTTI, 2010). Foi esta a estratégia aplicada nos três estados da região sul do Brasil, iniciando pelo Rio Grande do Sul, após Santa Catarina e Paraná.

Sendo o atual território do Paraná parte da província de São Paulo até agosto de 1853, notadamente, as iniciativas referentes à imigração e à instalação de colônias que aconteciam estavam localizadas, sobretudo para suprir a defasagem de mão de obra junto às fazendas cafeeiras paulistas e de agricultura de subsistência aos núcleos urbanos formados. No território da futura província do Paraná predominavam as fazendas de gado. Muitas estâncias haviam se formado em função da passagem dos tropeiros. Foram, naturalmente, estes fazendeiros que assumiram a vida política desta nova província.

O declínio desta atividade começou ainda no início do século XIX, quando então os olhares destes fazendeiros se voltaram para as florestas de araucária, as quais possibilitavam a diversificação da atividade para a extração da erva-mate ${ }^{4}$. Assim, desde o início da instalação da província, houve, por parte de seus governantes, o deslocamento de mão de obra e incentivo da exploração ervateira, sendo, nas décadas de 1840 e 1850, o principal produto exportado.

A futura ocupação da região do vale do Iguaçu seria motivada por questões políticas essencialmente. De acordo com Wachowicz (1976), a Confederação Argentina reivindicava o território da região de Palmas, no sudoeste da província, região onde habitantes dos povoados argentinos já estavam extraindo erva-mate. São fundadas as ocupações de Chapecó e Chopim, ambos em $1882^{5}$, e para ligar estas colônias à Capital e ao Porto de Paranaguá, foi retomada uma ideia antiga que combinava diversos meios de transporte.

Entre os anos de 1885 e 1886, o presidente da Província Alfredo d'Éscragnolle Taunay fundou onze entidades de apoio à imigração em onze cidades e vilas do Paraná. Foi necessário unir o governo provincial, câmara de vereadores de diversos municípios e entidades particulares para suprir a demanda (BALHANA;

\footnotetext{
${ }^{4}$ Segundo Wachowicz (1976), estas matas de araucária, que eram consideradas áreas devolutas até a presente época (décadas de 1840 e1850), eram também mais favoráveis à agricultura devido às características do solo

5 Assim como no Paraná, também, na antiga província do Rio Grande do Sul, em função da "questão de Palmas", diversas novas colônias foram instaladas no mesmo período, dentre elas, Guarany das Missões, ljuhy, Santa Rosa, Erechim (WACHOWICZ, 1976).
} 


\section{LUCENA,L.M.F. \\ PAISAGEM CULTURAL E ESPAÇOS DE REPRESENTAÇÃO. ANÁLISE DA COLÔNIA DE ÁGUA BRANCA, MUNICIPIO DE SÃO MATEUS DO SUL/PR}

PINHEIRO MACHADO; WESTPHALEN, 1969). A navegação do rio Iguaçu tornou viável a exploração e o transporte da erva-mate também, a qual começou no ponto onde está hoje situada a área urbana de São Mateus do Sul, região que se tornou propícia e necessária para instalação de colônias agrícolas.

No caso específico das colônias próximas à bacia do rio Iguaçu, suas localizações foram determinadas por fatores políticos (defesa e povoamento de fronteiras) e econômicos (desenvolvimento da agricultura), necessários para o desenvolvimento do sistema capitalista (falta de mão de obra).
O município de São Mateus do Sul e uma de suas colônias, a Colônia de Água Branca, foi o foco desta análise, como representação de um processo que se evidencia nos demais municípios da região sudeste do estado (figura 1).

Algumas destas colônias tiveram seu núcleo urbano bastante expandido sobre as áreas coloniais e muitas delas foram novamente parceladas, loteadas e se tornaram urbanas, como é o caso de algumas colônias de São Mateus do Sul, que será apresentado mais adiante. Em outras, o núcleo administrativo pouco se desenvolveu, como nos municípios de Antônio Olinto, Mallet, dentre outros.

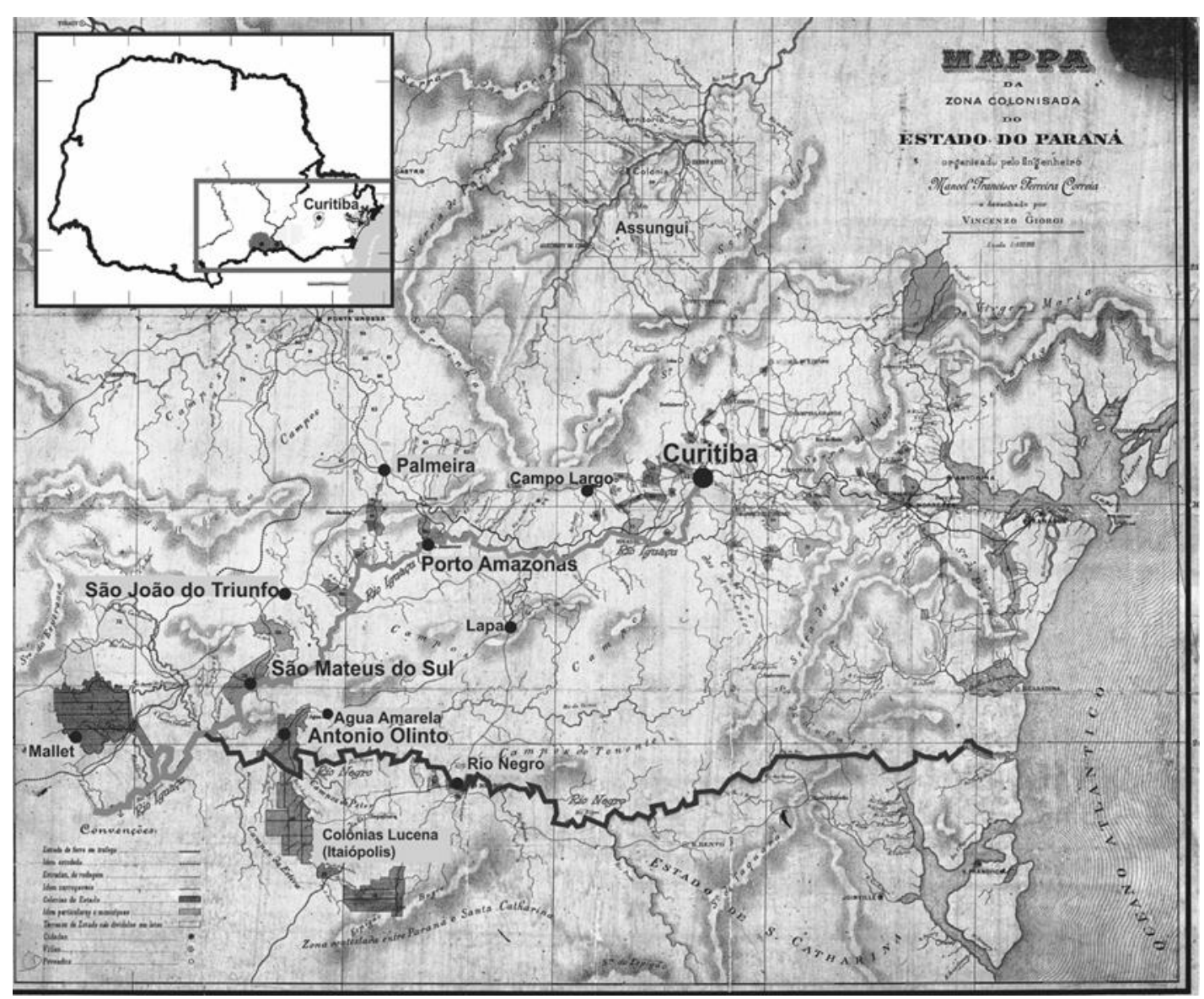

Figura 01 - Colônias Agrícolas em 1892. Legenda: as manchas escuras indicam a localização das colônias às margens do rio Iguaçu e Negro, algumas já instaladas e outras ainda não delimitadas, como é o caso de Paulo Frontin, Paula Freitas, União da Vitória, ao sul do estado. Fonte: ITCG (2013).

A antiga Colônia Maria Augusta, situada dentro da atual área do município de São Mateus do Sul, era composta por quatro linhas, que haviam sido nomeadas de Taquaral, Canoas, Iguaçu e Cachoeira (figura2).

Também foram instaladas em seguida, a Colônia Eufrozina (a 30 km de distância), ocupada 


\section{LUCENA,L.M.F. \\ PAISAGEM CULTURAL E ESPAÇOS DE REPRESENTAÇÃO. ANÁLISE DA COLÔNIA DE ÁGUA BRANCA, MUNICIPIO DE SÃO MATEUS DO SUL/PR}

por colonos ucranianos em sua maioria, e a colônia Água Branca (a $15 \mathrm{~km}$ ), ocupada por colonos poloneses essencialmente (figura 2); ambas instaladas em 1891 (LEÃO, 1994), independentes e distantes da Colônia Maria Augusta

Todas estas colônias foram instaladas em terras devolutas e provavelmente, em função da conexão que tinham com o rio Iguaçu, prosperaram. As linhas da antiga Colônia Maria Augusta, devido à proximidade com a área urbana, já foram descaracterizadas e incluídas na área urbana de São Mateus do Sul, mas aquelas mais distantes, Eufrozina e Água Branca, parecem ter preservado, seja voluntária ou involuntariamente, suas caraterísticas originais de implantação, isto é, o espaço concebido pelo governo estadual.

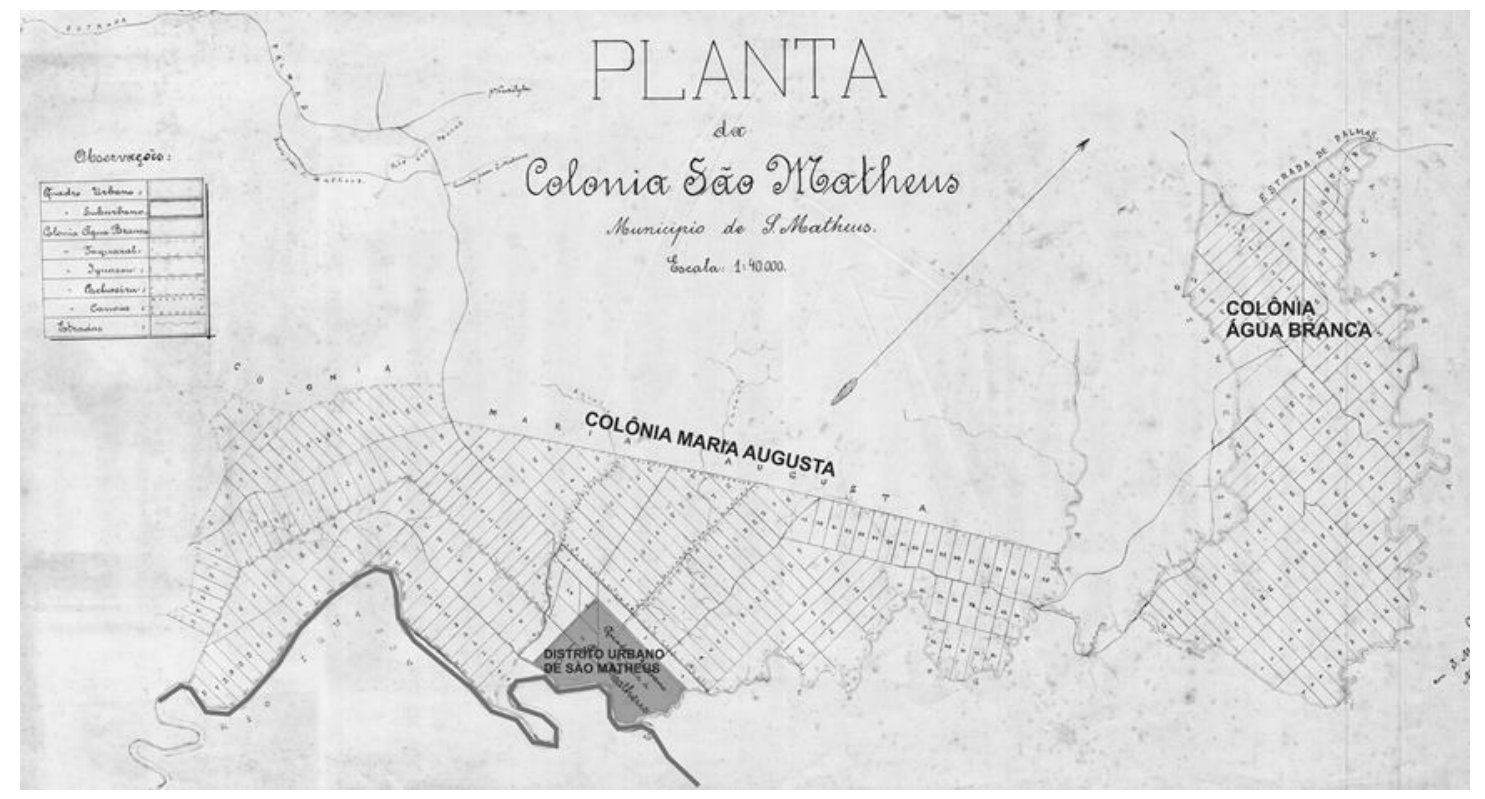

Figura 02 - Planta de Implantação da Colônia São Matheus com Demarcação da Colônia Maria Augusta (Composta Por Quatro Linhas) e a Colônia de Água Branca. Fonte: ITCG, 1938.

Por isso, foi escolhida para a análise desta pesquisa, a colônia de Água Branca, pois além de ser uma das colônias que está mais preservada fisicamente, esta tem sido apontada pelo próprio poder municipal como a que melhor mantém as características socioculturais que remonta ao início da história do município, já que tem a predominância da ocupação pelos poloneses. Além da presença de famílias tradicionais na região, preservam-se ainda muitos costumes dos primeiros imigrantes, como o uso da língua polonesa, algumas festas religiosas comemorativas que remetem aos costumes antigos, a preservação da igreja centenária, etc. Hoje, decorridos 125 anos de sua implantação, observa-se em Água Branca certa permanência dessa estrutura econômica e espacial inicialmente proposta.
Estes elementos permitiram conjecturar que, além da possibilidade de se caracterizar o espaço vivido lefebvriano, também, poder-se-ia definir que o conjunto destes espaços constituiria uma paisagem cultural sob o olhar da Geografia e, ainda, até sob o olhar dos órgãos de preservação cultural. É o que será desenvolvido a seguir.

\subsection{OS INDICATIVOS DE ÁGUA BRANCA À PAISAGEM CULTURAL}

A análise espacial da colônia de Água Branca revelou o processo de construção de sua paisagem, seu espaço vivido e os principais espaços de representação construídos historicamente e ainda perpetuados pelo grupo social que ali vive. 


\section{LUCENA,L.M.F. \\ PAISAGEM CULTURAL E ESPAÇOS DE REPRESENTAÇÃO. ANÁLISE DA COLÔNIA DE ÁGUA BRANCA, MUNICIPIO DE SÃO MATEUS DO SUL/PR}

A paisagem cultural de Água Branca modificou-se ao longo do seu processo de ocupação, tendo em vista que antes da chegada dos imigrantes toda a área era coberta por mata de araucária, entrecortada e banhada por alguns rios, córregos e, ocasionalmente, ocupada por grupos pequenos, "clandestinos" (aos olhos do governo) e desconhecidos (alguns faxinais). Este é o espaço percebido. Mas, após a intervenção do governo, é introduzida uma nova atividade na região, novos grupos de moradores e as colônias agrícolas estruturadas em minifúndios. Tem-se assim o planejamento e a introdução de uma nova atividade e ocupação espacial, o espaço concebido. Após a instalação dos imigrantes em seus lotes de terra, viveu-se um longo período de "estabilidade paisagística", pois a colônia se consolidou na sua atividade agrícola e extrativista e assim permanece até hoje, após 125 anos.
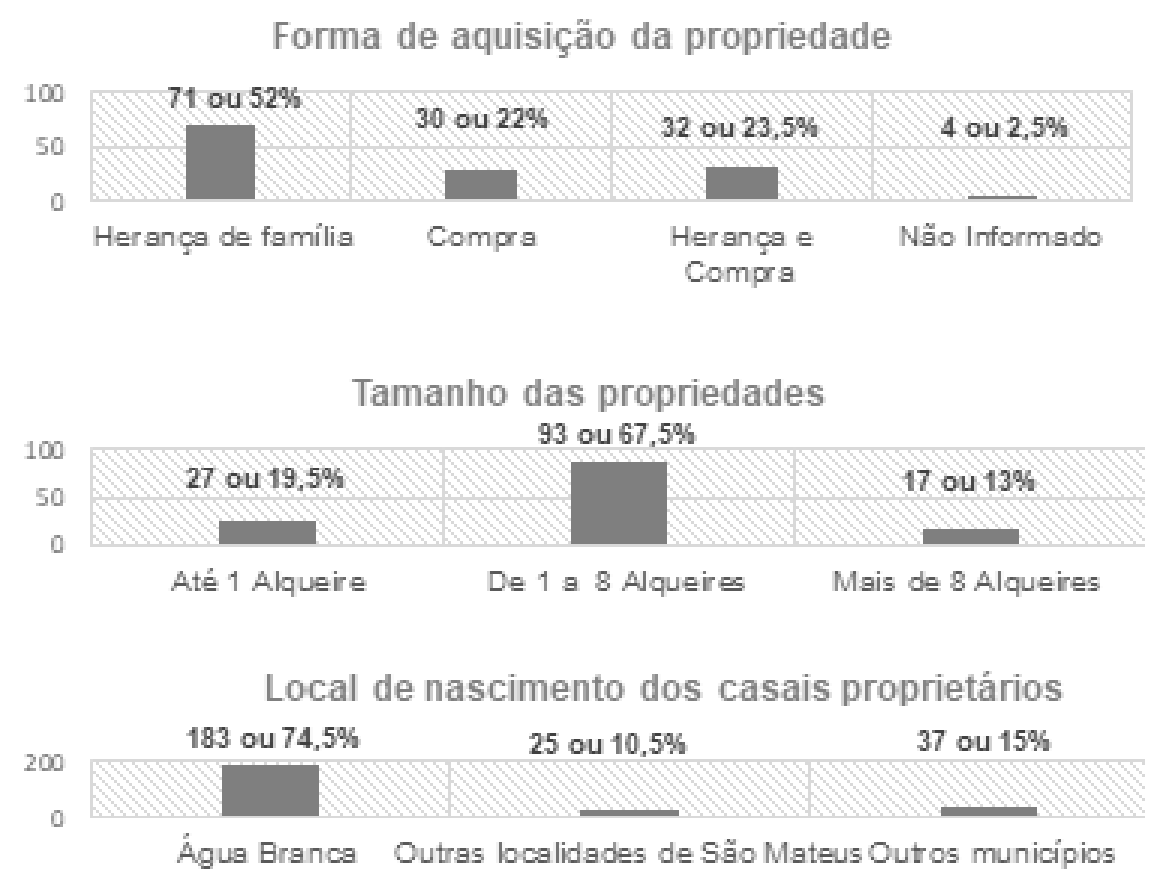

Gráfico 01 - Dados sobre a Colônia Água Branca. Fonte: Elaboração da autora, em abril de 2015.

Houve a preservação física dos mesmos caminhos e estradas abertas desde a implantação da colônia , assim como a divisão dos lotes, com média de 25 hectares, apesar de muitas famílias terem deixado a colônia ${ }^{6}$. As terras foram, na

\footnotetext{
6 Não se detectou na área, por exemplo, a compra de vários lotes de terra por um só proprietário ou a realização de remebramentos por algumas daquelas famílias ou por pessoas de outras localidades para a formação de grandes glebas de terras ou fazendas. É comum famílias comprarem lotes de terras isolados, ou seja, um lote em uma estrada, outro lote mais distante, às vezes na mesma ou noutra estrada
}

maioria, comercializadas entre vizinhos ou famílias da própria colônia, de maneira que o que se tem hoje é a ocupação da colônia em mais de $82 \%$ composta por descendentes dos primeiros imigrantes. Seus atuais proprietários, que correspondem, na maioria à terceira e quarta gerações destes imigrantes, guardam e transmitem à seus filhos valores ou princípios que talvez sejam os motivadores para manutenção da paisagem de Água Branca: o valor pela terra como fonte de subsistência e o valor pela história do local que está associada à vida e luta de seus avós e bisavós). 


\section{LUCENA,L.M.F. \\ PAISAGEM CULTURAL E ESPAÇOS DE REPRESENTAÇÃO. ANÁLISE DA COLÔNIA DE ÁGUA BRANCA, MUNICIPIO DE SÃO MATEUS DO SUL/PR}

Pela segunda etapa das entrevistas, de cunho qualitativo, possibilitou-se identificar o espaço vivido, a apropriação do morador sobre os espaços percebidos e concebidos, o que constitui a paisagem cultural de Água Branca, pois nela encontram-se alguns espaços de representação atuais e alguns perpetuados ao longo da formação histórica desta colônia. Seus espaços de representação podem ser hierarquizados, desde aquele mais individual - a casa e a terra onde nasceram e plantam, até o espaço público e coletivo cuja importância abrange não somente a comunidade, mas todos os descendentes de poloneses, que é a igreja de São José.

Alguns destes espaços de representação foram (re)significados sobre o espaço concebido (o espaço da igreja/cemitério, das estradas e da terra onde plantam), outros (re)significados sobre o espaço percebido (os rios, as matas). Inclusive muitos destes espaços têm se perpetuado por gerações e sua interligação, pela vida cotidiana, vem corroborar o conceito de paisagem cultural adotado pela Geografia e também, acredita-se, enquadrar-se no grupo minoritário e seleto da categoria paisagem cultural pelo IPHAN (órgão de preservação cultural). Por isso, as entrevistas buscaram realizar este percurso histórico na vida dos moradores, desde os mais antigos até os mais novos. Alguns dos lugares frequentados pelos idosos de hoje, quando crianças, se repetem com as crianças atuais, por exemplo. 0 resultado das entrevistas demonstra que, como a vida cotidiana destes moradores não mudou muito e não houve grandes interferências do governo (municipal, estadual ou federal) no espaço de Água Branca, com exceção do calçamento da rodovia PR-151 e da introdução de energia elétrica e de água encanada nas residências, estes espaços de representação mantiveram-se praticamente os mesmos ao longo destes 125 anos. Observou-se, sim, que alguns destes espaços mantiveram sua representatividade e importância, como é o espaço da igreja, e outros começam a ser esquecidos, como é o caso de algumas cruzes colocadas por alguns moradores (antigos locais de encontro para rezar) e que atualmente são lembradas em época de procissão, se ela passar por aquela região. Também os rios começam a perder sua representatividade em função do assoreamento que vem acontecendo; com isso os moradores têm procurado outros rios ou açudes particulares para pescar. Também, para concluir, a geração mais jovem tem opiniões controversas: enquanto alguns gostam e querem continuar em Água Branca, outros pretendem morar na cidade, identificando-se mais com a vida urbana. Podemos assim, sintetizar os espaços de representação para os três grupos entrevistados no quadro 1 abaixo:

Quadro 01 - Espaços de Representação para os Grupos Entrevistados, com seus respectivos Valores Sociais/Simbólicos Atribuídos no Espaço Vivido. Fonte: Elaborado pela Pesquisadora, a partir das Entrevistas Realizadas Em 2015.

\begin{tabular}{|c|c|c|c|}
\hline $\begin{array}{c}\text { Espaços de Representação } \\
\text { identificados } \\
\text { (pólos de socibilidade) }\end{array}$ & $\begin{array}{c}\text { Significados para o } \\
\text { Grupo } 1 \\
\text { (faixa dos } 80 \text { anos de } \\
\text { idade) }\end{array}$ & $\begin{array}{c}\text { Significados para o } \\
\text { Grupo } 2 \\
\text { (faixa dos } 60 \text { anos de } \\
\text { idade) }\end{array}$ & $\begin{array}{c}\text { Significados para o } \\
\text { Grupo } 3 \\
\text { (menores de } 25 \text { anos de } \\
\text { idade) }\end{array}$ \\
\hline Igreja/cruzes/cemitério & $\begin{array}{l}\text { Local de } \\
\text { espiritualidade/lazer }\end{array}$ & $\begin{array}{l}\text { Local de } \\
\text { espiritualidade/lazer }\end{array}$ & $\begin{array}{l}\text { Local de } \\
\text { espiritualidade/lazer }\end{array}$ \\
\hline $\begin{array}{l}\text { Casa e a terra onde } \\
\text { nasceram/viveram }\end{array}$ & Local de trabalho e lazer & Local de trabalho e lazer & Local de trabalho e lazer \\
\hline Escola (atrás da Igreja) & Local de trabalho e lazer & Local de trabalho e lazer & História/memória social \\
\hline Casa dos vizinhos/parentes & Local de trabalho e lazer & Local de trabalho e lazer & Local de lazer \\
\hline Rios Agua Branca e do Meio & Local de trabalho e lazer & Local de lazer & Local de lazer \\
\hline Associação polonesa & Local de lazer & Sem representação & Sem representação \\
\hline
\end{tabular}




\section{LUCENA,L.M.F. \\ PAISAGEM CULTURAL E ESPAÇOS DE REPRESENTAÇÃo. ANÁLISE DA COLÔNIA DE ÁGUA BRANCA, MUNICIPIO DE SÃO MATEUS DO SUL/PR}

Os moradores de Água Branca criaram vínculos emocionais (ou representações) sobre estes lugares ao longo de sua vida: a terra, a casa, a escola, a igreja. Estes espaços se tornam parte integrante da história da vida deles, contada individualmente e coletivamente, o que faz recordar a primeira trialética de Lefebvre, explicitada anteriormente neste trabalho: o existir depende da relação tempo - espaço sociedade.

As memórias de seus avós estão presentes na vida cotidiana destes moradores que tentam estimular seus filhos a falar polonês (a quinta geração), a continuar trabalhando nas lavouras, a ver a terra como representação de sobrevivência, segurança e futuro. Mantêm, até hoje, certos costumes no trato da terra e na divisão da mesma para organização das diversas atividades e a policultura: a horta e o jardim em volta de casa, a pequena criação mais aos fundos, como um galinheiro e a divisão da terra nas atividades extrativas (erva-mate), áreas para plantio de milho, feijão e arroz para consumo familiar e uma outra atividade mais extensiva para comercialização, seja soja ou fumo.

Assim, os espaços vividos ou de representação foram criados pelos grupos sociais que se apropriam destes espaços concebidos de acordo com suas necessidades e valores espirituais ou sociais, valorizando ou reformulando determinados aspectos ou locais segundo a história e as necessidades das novas gerações.

Foram identificados alguns espaços de representação que vêm sendo repetidos pelas três gerações entrevistadas, e esta característica aponta para a compreensão de que estes espaços, interligados pela vida cotidiana dos seus moradores, acabam por definir uma paisagem cultural sob o olhar da geografia e, provavelmente, também deverá, para os órgãos do patrimônio cultural.

Nos dias comuns, a vida cotidiana se expressa na casa, na terra, nas estradas rurais e nas estufas de fumo, pelo trabalho na lavoura ou nos afazeres da casa, cuja rotina é determinada pela época da colheita, pelo tempo para preparação da terra, pela mudança de cultura a ser plantada. Os caminhos e estradas ligam as atividades, consumidores e produtores, por onde passam os "tobatas" , tratores e caminhões com a produção. As atividades nos finais de semana podem diferenciar-se ou não dos dias úteis, depende de qual é a fase da cultura - semeadura, capinagem, colheita, adubação, ou do tempo, pois a chuva é boa em algumas épocas, em outras atrapalha. Mas sempre se reserva um tempo para ir à missa, levar os filhos à catequese, ou fazer uma visita a um parente ou vizinho; os mais idosos já não vão com tanta frequência à igreja.

Nos dias de festa, a rotina diária é interrompida. As festas acontecem na igreja e no galpão construído bem próximo à ela: Páscoa, "Corpus Christi", o padroeiro São José, a Padroeira da Polônia ${ }^{8}$, Natal. Também alguns "jantares" e pequenas festas (como a festa junina) são feitos para arrecadar fundos para as festas principais. Existe ainda o tempo para a preparação das festas, que envolve dias antes, especialmente as mulheres e as crianças: enfeites para o local, ensaio de danças, músicas, etc., dependendo do motivo de cada festa. Os homens ajudam, principalmente, no dia, quando se exige força física para organizar o espaço. A festa acontece na igreja, no entorno da igreja e, às vezes, como na festa da padroeira da Polônia, algumas estradas também são enfeitadas, mudam de função.

Estas práticas espaciais preservam espaços, arquiteturas e paisagens. Por isso, só reconhecer a beleza arquitetônica e a tecnicidade da construção em madeira da igreja, bem como a originalidade de suas pinturas internas não seria suficiente. Ela se mantém até hoje porque a população que ali vive, frequenta e quer preservá-la na forma como está, tem valor histórico e simbólico para seus usuários. Foram seus avós, bisavós que a construíram com muita dificuldade. A igreja, como materialidade, tem papel preponderante na convergência social dos habitantes da colônia de Água Branca.

Também, a vida cotidiana dos moradores de Água Branca, em suas práticas sociais, segue

\footnotetext{
${ }^{7}$ Espécie de trator pequeno, usado para atividades de remoção da terra ou transporte da colheita, quando a ele é anexada a carroça

${ }^{8}$ Nossa Senhora de Monte Claro ou Nossa Senhora de Czestochowa.
} 


\section{LUCENA,L.M.F. \\ PAISAGEM CULTURAL E ESPAÇOS DE REPRESENTAÇÃO. ANÁLISE DA COLÔNIA DE ÁGUA BRANCA, MUNICIPIO DE SÃO MATEUS DO SUL/PR}

certa rotina e tradicionalidade, em função dos seus valores simbólicos pela terra e por aquele local onde nasceram: a permanência da agricultura familiar, a policultura, os hábitos de fazer o pão, o queijo, o requeijão, o "pierogi" , "holopti", além de criar o porco, fazer alguns embutidos e conservas. A vida cotidiana e seus valores pela terra fazem com que a paisagem de Água Branca tenha, de alguma forma, se estabilizado. Alguns órgãos públicos "interagem" nesta paisagem, como é o caso do Instituto Ambiental do Paraná (IAP), que exige a preservação das araucárias, das matas ciliares, e de uma porcentagem das terras como área de reserva ambiental, porém, esta legislação não tem incomodado muito estes moradores. Recentemente a população solicitou e conseguiu o tombamento estadual da igreja, visando à possibilidade de adquiris recursos financeiros para a restauração da mesma.

Pelo exposto, as características desta paisagem acenariam como potencialidades para uma chancela a ser efetuada pelo IPHAN. A delimitação desta área a ser chancelada (figura 3), certamente, passaria por um estudo topográfico, de maneira que abrangesse toda a área reconhecida pelos moradores em seu espaço vivido, além da área concebida para a colônia em seu projeto inicial feito pelo DTCG ${ }^{9}$, em 1890.
Há uma diferença entre a junção do espaço concebido e vivido e a proposta de delimitação desta área: acrescenta-se uma área de entorno, que inclui a área do Faxinal dos Ilhéus, devido a relação física e social intensa que esta comunidade tem com Água Branca e como precaução para evitar impactos visuais e ambientais na colônia que possam vir a comprometer a permanência e o estilo de vida dos seus moradores. Consolida-se também uma área para fins urbanos, com usos comerciais de varejo e equipamentos públicos. A área da Igreja e seu entorno, já tombada pelo governo estadual, é também considerada nesta proposta apresentada. O conjunto de arruamentos rurais deveriam permanecer, assim como o uso do solo, que deveria ser mantido como rural, proibindo industrias ou outros usos. Cada um dos espaços de representação tem sua importância, mas certamente a área da Igreja e suas atividades merecem maior atenção, pois deste espaço simbólico desdobram-se outras atividades (festas, encontros religiosos, etc.) que estendem sua área de influência para algumas estradas rurais. É o espaço de representação de uso coletivo mais importante para a comunidade de Agua Branca.(figura 4).

\footnotetext{
${ }^{9}$ Atual ITCG.
} 

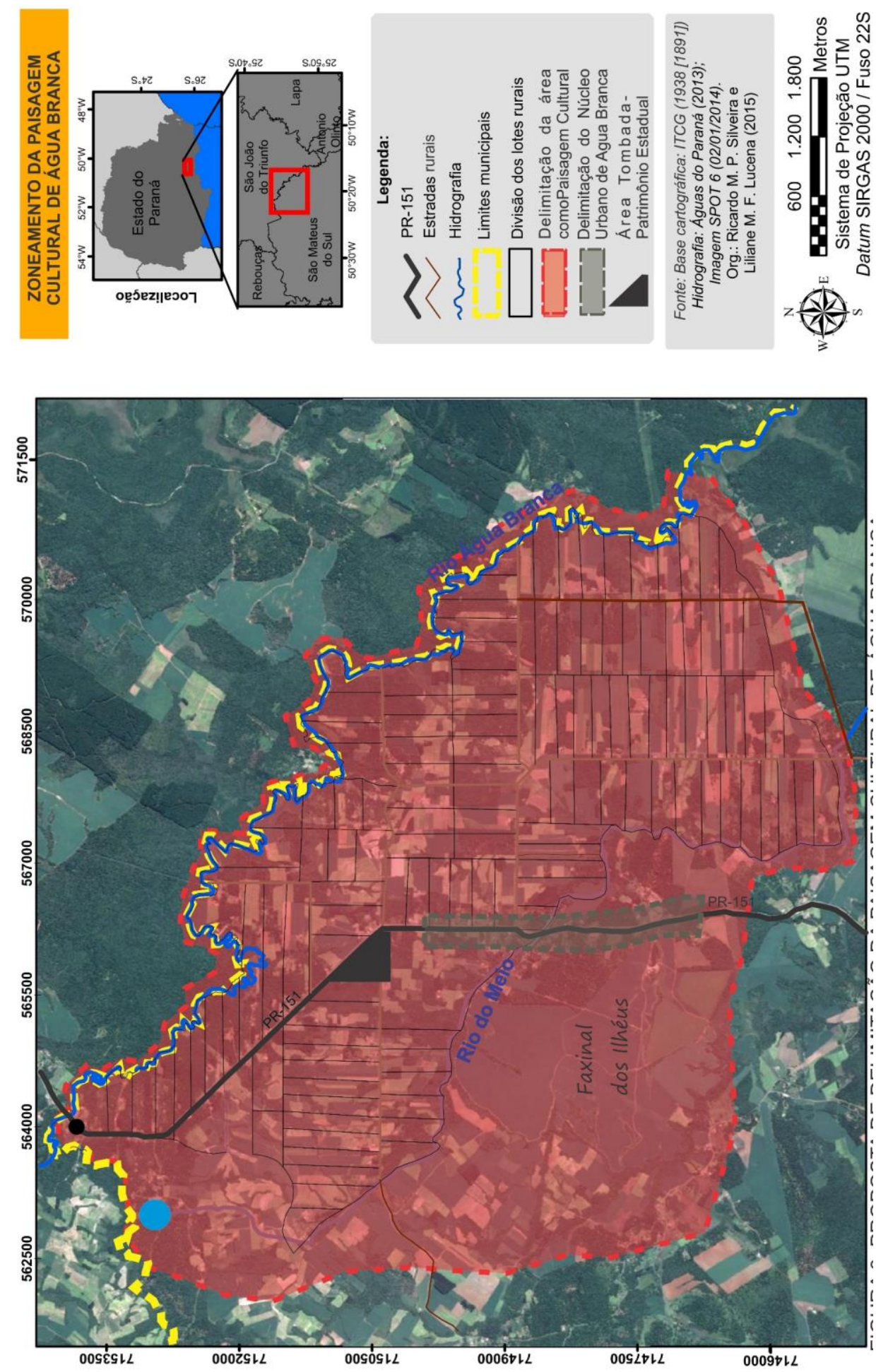

Figura 03 - Proposta de Delimitação da Paisagem Cultural de Agua Branca. Fonte: Elaborado pela pesquisadora sobre a Imagem SPOT6 (02/01/2014) 


\section{LUCENA,L.M.F. \\ PAISAGEM CULTURAL E ESPAÇOS DE REPRESENTAÇÃO. ANÁLISE DA COLÔNIA DE ÁGUA BRANCA, MUNICIPIO DE SÃO MATEUS DO SUL/PR}

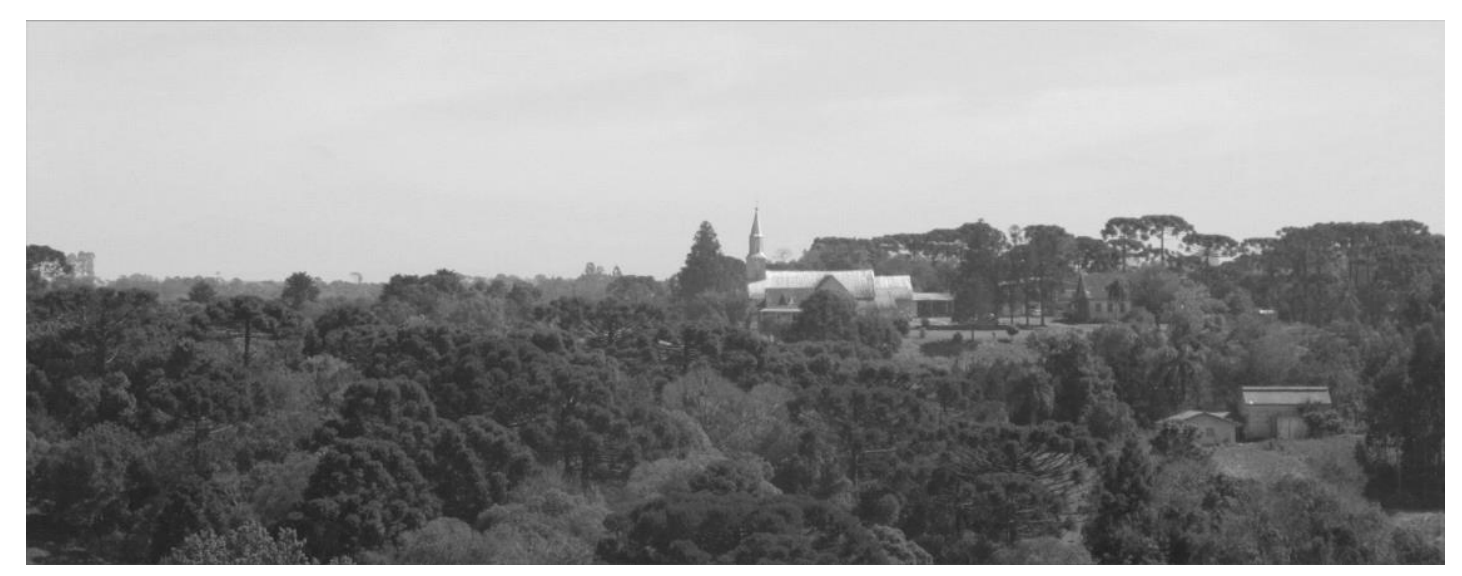

Figura 04 - Vista Geral da Colônia com Enfoque para a Igreja de Água Branca. Fonte: acervo da Pesquisadora,2015.

\section{CONSIDERAÇÕES FINAIS}

A caracterização do espaço vivido em Lefebvre permite identificar elementos históricos importantes para o grupo, como trajetos, lugares, arquiteturas e paisagens. As atividades cotidianas e festivas do grupo localizam, definem e delimitam estes lugares: os locais de trabalho e circulação, os locais de lazer, das festas, do encontro e da sociabilidade. A análise do espaço vivido em Água Branca permitiu localizar estes lugares e perceber no discurso dos seus moradores a delimitação física desta colônia e suas fronteiras com outras localidades, lembrando a afirmação de Almeida (2010, p. 10), quando enfatiza que "a territorialidade define uma relação individual ou coletiva ao território e se apoia sobre as paisagens", e que "a paisagem e o território são dimensões marcadas por elementos patrimoniais, signos da trajetória da sociedade que ativam a memória e situam os grupos definindo suas identidades" (ALMEIDA, 2013, p. 417).

Assim, a paisagem cultural que se define aqui é aquela que corresponde ao espaço vivido dos moradores de um determinado lugar, que atende aos requisitos para ser caracterizada dessa forma pela Nova Geografia Cultural e que também poderia ser a paisagem cultural delimitada como patrimônio cultural. A territorialidade definida pelo espaço vivido é uma característica importante que poderá contribuir para a delimitação de uma área como paisagem cultural, seja no âmbito da Geografia Cultural, seja do ponto de vista dos órgãos de preservação histórica e cultural.

$O$ instrumento da chancela, criado recentemente na forma de portaria do IPHAN, tem o caráter de ser um instrumento de reconhecimento e valorização, baseado na motivação entre os parceiros, interessados na preservação.

A definição de paisagem cultural adotada pelo IPHAN não se diferencia do conceito adotado pela Nova Geografia Cultural, mas cria alguns critérios a mais que acabam por restringir/reduzir este conjunto. O principal critério é buscar uma "peculiaridade", uma excepcionalidade que possa representar uma característica (histórica, social e ambiental) da paisagem brasileira, reduzindo-se, significativamente, o universo de paisagens culturais que se tem no território nacional. Criase, dessa forma, um subgrupo dentro do grupo das paisagens culturais (referindo-se ao início deste capítulo, entre as paisagens que possuem valor simbólico e as que não o possuem), que 


\section{LUCENA,L.M.F. \\ PAISAGEM CULTURAL E ESPAÇOS DE REPRESENTAÇÃO. ANÁLISE DA COLÔNIA DE ÁGUA BRANCA, MUNICIPIO DE SÃO MATEUS DO SUL/PR}

podem ser denominadas "paisagens culturais patrimoniais". Assim acontece também entre as centenas de milhares de imóveis históricos ou centros históricos brasileiros quando alguns deles são tombados e outros não. Busca-se sempre aquele imóvel ou sítio que possa melhor "representar" seu conjunto, "que dá testemunho de uma civilização particular, de uma evolução significativa ou de um acontecimento histórico" (IPHAN, 1964). Nesse sentido, explicita Weissheimer (2012) que é pela característica da "peculiaridade" que uma determinada área territorial será selecionada para obtenção da chancela. Ou seja, há necessidade de definir "critérios" para a aplicação do paisagem cultural como instrumento de proteção.

Nessa perspectiva, a instituição definiu estes critérios de valoração e diferenciação entre uma paisagem que merece ser chancelada $\mathrm{e}$ outra não. São basicamente dois: a existência de bens materiais e imateriais relacionados ao meio ambiente, os quais mereceriam ser tombados e ou registrados, e a convergência de interesses de preservação com outros órgãos municipais, estaduais e/ou federais (IPHAN, 2009a, p. 17). A chancela surge como ferramenta complementar de compreensão do contexto ambiental no qual estes elementos materiais e imateriais se manifestam e se relacionam, pois "tem por finalidade atender ao interesse público e contribuir para a preservação do patrimônio cultural, complementando e integrando os instrumentos de promoção e proteção existentes nos termos preconizados na Constituição Federal". (IPHAN, 2009a, p. 17). Portanto, dentro de uma área ou território chancelado haverá certamente imóveis ou áreas tombadas e/ou bens registrados. Não ocorrerá o inverso, ou seja, realizar um estudo de chancela sem que na área não existam tombamentos e/ou registros.

No entanto, considera-se que a realização de uma análise espacial sobre um sítio como paisagem cultural possui uma profundidade de estudo muito maior. A análise da paisagem como espaço vivido permite identificar elementos materiais (arquiteturas, ecossistemas, fauna e flora) e imateriais existentes (ofícios, festas, formas de subsistência do homem ao local), bem como suas relações entre estes elementos e destes com o meio, construídas historicamente. Mais ainda, esta metodologia evidencia a importância (ou representações) que os moradores atribuem aos lugares e edificações, tornando-se eles os primeiros interessados na preservação. O centro das atenções numa análise espacial e/ou paisagística (pela proposta desenvolvida neste trabalho) é o homem em sua apropriação do meio ambiente, enquanto numa análise de tombamento ou registro, o foco da análise é o imóvel ou a festa, cujas análises são feitas para compreender o papel, a importância deste bem naquele ambiente e sociedade.

Com isso, propõe-se aqui refletir: o tombamento de um centro histórico guarda a riqueza urbana e arquitetônica construída (histórica política, econômica, tecnológica, etc.) mas não evidencia ou valoriza as formas de uso dos seus espaços arquitetônicos e públicos da vida cotidiana ou das festas que existem no lugar. Para isso tem-se que realizar outro estudo que valorize a subjetividade, o simbolismo que a população residente tem pelo lugar e que não é salientada, mas existe e dá vida àquele centro histórico. Da mesma forma, ao estudar o registro de uma festa religiosa ou pagã, que percorre um trajeto espacial, que tem seus tempos e personagens marcados em determinados pontos; estas festas são também realizadas sobre uma base espacial e arquitetônica. A manutenção de algumas destas festas, ofícios e artes depende da preservação espacial que os alicerça. Assim, fica claro que a proposta de se chancelar uma paisagem só é cogitada quando o instituto percebe a existência de um conjunto de bens materiais e imateriais no local (evidenciados pelos estudos de inventários) que dependem do meio ambiente para se manter.

O que esta pesquisa demonstra, na verdade, é que uma inversão dos métodos de reconhecimento de patrimônios (materiais e imateriais) e das chancelas seria mais completa/integral, ao se realizar uma inversão na ordem dos mesmos, ou seja: parte-se da análise espacial e identificação do espaço vivido. Após a 


\section{LUCENA,L.M.F. \\ PAISAGEM CULTURAL E ESPAÇOS DE REPRESENTAÇÃO. ANÁLISE DA COLÔNIA DE ÁGUA BRANCA, MUNICIPIO DE SÃO MATEUS DO SUL/PR}

análise do espaço, a identificação da paisagem cultural como espaço vivido e dos espaços de representação contidos nesta paisagem, tem-se tanto a delimitação de uma área, uma territorialidade, quanto a identificação de todos os elementos materiais e simbólicos que são importantes para o grupo que ali reside.

A partir deste conjunto, pode-se eleger aqueles espaços que deveriam ser tombados e registrados, aqueles que podem ser englobados na área por serem "coadjuvantes" do espaço vivido e até já possuírem alguma outra legislação que os preserve, como as leis ambientais, o que envolveria outros órgãos (municipais, estaduais e/ou federais).

Esta seria, talvez, uma mudança metodológica bastante radical, mas que enriqueceria qualquer análise e identificação de um bem como patrimônio. Ao se propor a identificação de um patrimônio histórico no município, por exemplo, ou de um centro histórico, a análise espacial amparada pela teoria de Lefebvre aponta não só os elementos construídos, os espaços concebidos (públicos e particulares) como as praças, largos, igrejas, etc., mas também as relações cotidianas, as formas de apropriação pelo trabalho, lazer e as festas que dão sentido, ambiência e vida àquele lugar, tornando-se, assim, fácil a identificação de propostas de tombamentos e de registros, sobretudo a compreensão do conjunto como uma paisagem cultural que é inseparável. Por isso, a compreensão do "espaço social" lefebvriano revela-se aqui como método de análise para identificação de espaços, arquiteturas, formas espaciais e paisagens representativas para aquele grupo social que $o$ gerou, coincidindo novamente com a paisagem cultural estudada pela nova Geografia Cultural. Ou seja, tanto na visão do IPHAN como para Lefebvre e na Geografia Cultural, todos reconhecem que existem diversos atores construindo este espaço/paisagem, e que para cada um destes atores existe um valor social atribuído. Para estas três visões, também, é o valor social atribuído pelos próprios moradores o que mais importa, pois são eles que, dia a dia, vivenciam, interagem, participam daquele espaço/paisagem.

Desse modo, o que este trabalho demonstra é que a utilização deste método, que evidencia a paisagem cultural como espaço vivido, traz uma forma mais "integrada" de identificação e constituição de uma paisagem cultural, seja na visão da Geografia, seja na visão do IPHAN, pois analisa o processo social e histórico de construção do espaço (social), evidenciando os agentes atuantes, as ideologias, as formas de materialização destas ideologias e as formas de apropriação ou não destas materializações, sejam elas arquiteturas, praças, monumentos, vilas, ou cidades inteiras. Neste processo, os espaços de representação são evidenciados por serem representativos dos valores sociais daquele grupo que o materializou. $E$, na verdade, todo trabalho de pesquisa, identificação e proposta de tombamento e/ou registro poderia iniciar pela análise espacial de Lefebvre.

\section{REFERÊNCIAS}

ABRAMOVAY, R. Paradigmas do capitalismo agrário em questão. São Paulo-Rio de JaneiroCampinas. Editora Hucitec, ANPOCS, Editora Unicamp, 1992.

BALHANA, A.P.; PINHEIRO MACHADO, B; WESTPHALEN, C. História do Paraná. Curitiba: Grafipar, 1969.

GIL FILHO, S. F. Espaço de representação: uma categoria chave para a análise cultural em geografia. [on line]. 2003. Disponível em:<http://br.monografias.com/trabalhos917/es paco-representacao-geografia/espacorepresentacao-geografia2.shtml

Geografia Cultural: estrutura e primado das representações. Espaço e Cultura, Rio de Janeiro, n. 19-20, p. 51-59, 2005. Disponível em: $<$ http://www.e-

publicacoes.uerj.br/index.php/espacoecultura/ar ticle/view/3491/2419>. Acesso em: 26 abr. 2015.

IOTTI, L. H. A política imigratória brasileira e sua legislação - 1822-1914. In: X ENCONTRO ESTADUAL DE HISTÓRIA. Anais... Santa Maria/RS, 2010. 


\section{LUCENA,L.M.F. \\ PAISAGEM CULTURAL E ESPAÇOS DE REPRESENTAÇÃO. ANÁLISE DA COLÔNIA DE ÁGUA BRANCA, MUNICIPIO DE SÃO MATEUS DO SUL/PR}

IPHAN. Instituto do Patrimônio Histórico e Artístico Nacional. Portaria no 127, de 30 de abril de 2009a. Diário Oficial da União, n. 83, p. 17, terça-feira, 5 de maio de 2009, seção 1 . Disponível em: <http://sigep.cprm.gov.br/destaques/IPHAN_por taria127_2009PaisagemCultural.pdf>. Acesso em: 5 jun. 2012.

ITCG. Instituto de Terras Cartografia e Geociência do Paraná. Planta de Implantação da Colônia de São Mateus do Sul. 1938. (cópia digitalizada).

KAUTSKY, K. A questão agrária. Tradução de C. IPEROIG. RJ: Gráfica Editora Laemmert S.A., 1968.

LEFEBVRE, H. La production de l'espace. Paris: Ed. Antropos, 1974.

La presencia y la ausencia. Contribución a la teoría de las representaciones. México: Fondo de Cultura Económica,1983. Obra republicada pelo FCE, em 2006 [1980].

.Critique of Everyday Life: Introduction.UK: London; USA: New York: Verso, 1991 [1968]. v. I.

LEÃO, E. Dicionário Histórico e Geográfico do Paraná. Instituto Histórico e Geográfico e Etnográfico Paranaense, Curitiba, 1994. v. I.

LUCHIARI, M. T. D. P. A (re)significação da Paisagem no período contemporâneo. In: ROSENDAHL, Z.; CORRÊA, R. L. (Org.). Paisagem, Imaginário e Espaço. Rio de Janeiro: EdUERJ, 2001. p. 9-27.

MARQUES, M. I. M.; BARRETO, M. (tradutores). A teoria da produção do Espaço de Henri Lefèbvre: em direção a uma dialética tridimensional.
Revista GEOUSP - espaço e tempo, São Paulo, n. 32, p. 89-109, 2012.

MORESI, E. (Org.). Metodologia de Pesquisa. Brasília, Universidade Católica de Brasília, 2003. Disponível em: http://www.inf.ufes.br/ falbo/files/Metodologia Pesquisa-Moresi2003.pdf. Acesso em: 15 de março de 2015.

PRADO JR., C. Formação do Brasil contemporâneo. 9. ed. São Paulo: Brasiliense, 1969.

SOJA, E. W. Thirdspace: journeys to Los Angeles and other real-and-imagined places. Massachussett, USA: Blackwell Publishing, 1996.

UNESCO. Organização das Nações Unidas para a Educação, a Ciência e a Cultura. Convenção do Patrimônio Mundial, 1999. IPHAN. Cartas Patrimoniais. IPHAN, 3. ed. 2000. Disponível em: <http://portal.iphan.gov.br/pagina/detalhes/226 >. Acesso em: 12 mar. 2014.

WACHOWICZ, R. C. A Transformação da Propriedade Fundiária no Vale do Rio Iguaçu. In: VIII SIMPÓSIO NACIONAL DOS PROFESSORES UNIVERSITÁRIOS DE HISTÓRIA - ANPUH. Anais eletrônicos... Aracaju, setembro 1976. Disponível em: <http://anpuh.org/anais/wpcontent/uploads/ANPUH.S08.pdf>. Acesso em: 08 set. 2014.

TCHAYANOV, A.V. Teoria dos sistemas econômicos não capitalistas. Análise Social, Lisboa: Revista do Instituto de Ciências Sociais da Universidade de Lisboa, ano XII, n.46, p.477-502, (1976 [1924]) 